\title{
Mobbing in Higher Education: Descriptive and Inductive Case Narrative Analyses of Mobber Behavior, Mobbee Responses, and Witness Support ${ }^{*}$
}

\author{
Jale Minibas-Poussard ${ }^{1}$ \\ Institute of Management \\ Research \\ (IRG-EA2354) \\ Université Paris-Est
}

\author{
Tutku Seckin-Celik ${ }^{2}$ \\ Istanbul Medeniyet \\ University
}

\author{
Haluk Baran Bingol ${ }^{3}$ \\ Global South Research \\ Consortium
}

\begin{abstract}
Previous studies investigated relationships between mobbing and increased workplace and interpersonal conflict at institutional settings, social-economic-cultural variables of the work environment, and job content, along with the economic and health outcomes of mobbing. Our mixed method research particularly focuses on mobbing in both public and private higher education institutions in the light of two consecutive studies in Turkey: a descriptive quantitative research based on survey data $(\mathrm{N}=481)$ followed by a deeper qualitative analysis of case narratives collected from a smaller sample $(\mathrm{N}=19)$. Exploring the interrelations between mobbing/mobber behavior, mobbee responses, and witness support based on multi-criteria frameworks of mobbing, our study revealed the superior level of mobbing at public settings compared to private, and the prevalence of affiliation related to mobbing. The analysis of case narratives revealed how favoritism, personal hostility, differences in political/religious thoughts were the main causes of mobbing while most of the mobbing came from superiors. Narratives also confirmed the descriptive study on witness support since we observed it playing an overall significant role in the mobbing behavior, mobbee responses and the work environment.
\end{abstract}

Keywords

Mobbing $\bullet$ Bullying $\bullet$ Higher education $\bullet$ Cases $\bullet$ Turkey

\footnotetext{
* Survey data was collected as part of the master's thesis of Tutku Seckin-Celik.

1 Correspondence to: Jale Minibas-Poussard, Institute of Management Research (IRG-EA2354), Université Paris-Est, UPEC, UPEM, Créteil, France. Email: jale-hatice.minibas-poussard@u-pec.fr \& mpjale@gmail.com

2 Department of Management, Istanbul Medeniyet University, Turkey. Email: tutkuseckin@gmail.com

3 Global South Research Consortium, Atlanta, USA. Email: hbaranbingol@gmail.com

Citation: Minibas-Poussard, J., Seckin-Celik, T., \& Bingöl, H. B. (2018). Mobbing in higher education: Descriptive and inductive case narrative analyses of mobber behavior, mobbee responses, and witness support. Educational Sciences: Theory \& Practice, 18, 471-494. http://dx.doi.org/10.12738/estp.2018.2.0018
} 
Mobbing has emerged as a hot topic in the contemporary global scholarship, and research on mobbing has gained significance and depth in the last decade. Based on their study in the UK, Hoel and Cooper (2000) observed that mobbing is more frequently observed in higher education compared to other industries. Keashly and Neuman (2010) suggested that researchers must pay more attention to aggressive behavior and mobbing in the higher education. They emphasized that in the higher education systems of Scandinavian countries, UK and USA, mobbing is more significant than the general population. In American universities, mobbing reaches $32 \%$ (Keashly \& Neuman, 2008) while it is around 52\% in Canada (McKay, Arnold, Fratzl, \& Thomas, 2008), 65.3\% in New Zealand (Raskauskas, 2006), and 49.7\% in Pakistan (Ahmad, Kalim, \& Kaleem, 2017).

Research focus on mobbing in Turkey's higher education system has been also growing in recent years. Cogenli and Asunakutlu (2016) report that $66.8 \%$ of 400 faculty members in 10 different universities were exposed to mobbing. Apaydin (2012) also reports that $27 \%$ of 320 faculty members from 28 universities experienced mobbing. Moreover, lower rates were observed in the studies of Yelgecen-Tigrel and Kokalan (2009), and Tanoglu, Aricioglu and Kocabas (2007) that are respectively: $11.6 \%$ and $15.8 \%$, while much higher rates were observed in the study of Gul, Ince, and Ozcan (2011) which is $70 \%$.

Both global and Turkish literature on mobbing experienced by faculty members is limited in terms of empirical research, therefore, we aim to observe the level and scope of mobbing experienced by faculty members in Turkey's universities. Designed as a stepwise mixed-method research, two components of our study are: (i) a descriptive study based on a survey we conducted in Turkey which investigates the interlinkages between mobbing/ mobber behavior, mobbee responses, and witness social support, followed by (ii) the analysis of longitudinal case narratives that both comparatively checks the significance between qualitative and quantitative relationships, and also controls for latent variables or deviations that are not captured nor expressed in the quantitative study.

\section{Conceptual Framework for Mobbing Research}

Leymann (1990, p. 120) defines mobbing as hostile and unethical behavior directed towards one or more individuals putting them in defenseless or hopeless situations systematically at least once a weak and within a six months period. While some researchers use the term "bullying", Leymann preferred "mobbing". Hence, according to Leymann (1996), bullying refers more to the use of physical force or violence, while subtle or covert aggressive behaviors are exercised in workplaces. Today, both terms are being used interchangeably. For example; according to Zapf (1999, p. 70) mobbing/bullying is a source of excessive social stress including 
systematic hostile behavior in long-term periods towards individuals targeted. The most widely used definition in international publications comes from Einarsen, Hoel, Zapf, and Cooper (2011, p. 22): "Bullying at work means harassing, offending, socially excluding someone, or negatively affecting someone's work tasks. In order for the label bullying (or mobbing) to be applied to a particular activity, interaction, or process, it has to occur repeatedly and regularly (e.g., weekly) and over a period of time (e.g., about six months). Bullying is an escalated process in the course of which the person confronted ends up in an inferior position and becomes the target of systematic negative social acts."

Although many researchers point out that aggressive behavior, repetition, duration, lack of power balance, and visible hostile and destructive aim are common characteristics of mobbing, they proposed different criteria to label a workplace aggression as mobbing. Leymann (1996) emphasized aggressive behavior in the diagnosis of mobbing, and others have identified at least two hostile behaviors occurring (Lutgen-Sandvik, Tracy, \& Alberts, 2007; Mikkelsen \& Einarsen, 2001; Salin, 2001). Repetition or frequency of aggressive behavior must be at least once a week (Leymann, 1996; Lutgen-Sandvik et al., 2007) or twice a week (Mikkelsen \& Einarsen, 2001) as a second component of the diagnosis. Also, scholars generally agree on the duration to be at least six months as the third component (Hoel, Cooper, \& Faragher, 2001; Leymann, 1996; Zapf, Knorz, \& Kulla, 1996). Moreover, power imbalance between the parties was also identified to be essential in defining mobbing (Einarsen \& Mikkelsen, 2003; Hoel \& Cooper, 2000).

Mobbing reveals itself with negative and aggressive behavior. Individuals experiencing mobbing may not be aware, nor realize that these behaviors represent mobbing because behaviors that can be confronted by everyone in every work place carry different meanings throughout the mobbing process. Researchers have brought about different categorizations such as Leymann (1996) who determined 45 types of mobbing behavior in five categories that are: (i) Towards the communication possibilities of mobbee (e.g. to be yelled at, or to be scolded), (ii) Towards the maintenance of social contacts of mobbees (e.g. not permitted to talk or meet with anyone), (iii) Towards the maintenance of personal reputation of mobbees (e.g. gossips or false rumors), (iv) Towards mobbees' occupational situation (e.g. being avoided from tasks or given irrelevant tasks), (v) Towards mobbees' physical health (e.g. physical threats or assaults).

Grounded on the 45 mobbing behavior of Leymann (1996) or case studies, various categorizations were proposed for mobbing. For example, Zapf et al. (1996) proposed seven mobbing behavior groups in their psychological mobbing analysis: attack the mobbee with organizational measures, attack the mobbee's social relationships 
with social isolation, attack the mobbee's private life, physical violence, attack the mobbee's attitudes, verbal aggression and rumors. Besides, Einarsen, Hoel, and Notelaers (2009) categorized mobbing behaviors in three groups: mobbing related to work (e.g. hiding information that may impact mobbee's performance), mobbing related to individual (e.g. gossips, false rumors, groundless accusation), and mobbing related to physical threats (e.g. blocking the way of mobbee, pushing, scaring).

\section{Causes of Mobbing}

Scholars have made various propositions as to the causes of mobbing. Besides the proponents of the view that personal characteristics of the mobbee/mobber play a role (Glasø, Matthiesen, Nielsen, \& Einarsen, 2007; Persson et al., 2009) and others highlighting organizational factors (Leymann, 1996; Salin, 2003), some scholars suggest it is more appropriate to consider all factors related to the mobbee, mobber, and organization altogether when looking at the causes of mobbing, instead of a sole factor (Hauge, Skogstad, \& Einarsen, 2009; Zapf, 1999).

In mobbing processes, mobbers view themselves more positively than they are, have inaccurate and uncertain thoughts about their good characteristics, grow jealousy towards newly individual hires, and feel threatened by their self-esteem and values, thus engage in violent behavior (Vartia, 1996; Zapf \& Einarsen, 2011, p. 182). Aggressive behaviors are initiated by the mobbers because of the lack of social capabilities such as anger management, or because they are motivated to preserve their positions by weakening mobbees' prestige (Salin, 2001; Zapf \& Einarsen, 2011, p. 180).

Studies grounded on the five factors model show how mobbees are more dependent compared to aggressors, more introverted, more responsible, and emotionally less stable (Glasø et al., 2007; Lind, Glaso, Pallesen, \& Einarsen, 2009). Bowling, Beehr, Bennett, and Watson (2010) suggested that having negative psychology and weak self-esteem leads to the perception of mobbees as easier targets, and mobbers more frequently select individuals with these characteristics. Although victims display different personal characteristics compared to others, it is not appropriate to view these characteristics as the causes of mobbing since there is an ambiguity as to whether they lead to the formation of aggressive behaviors (Persson et al., 2009).

Leymann (1996) asserts that mobbing is not related to individual factors, only organizational factors must be held accountable. The changing structure of workplace shows itself with restructuring, recession, decreasing the number of personnel in organizations, and this triggers mobbing (Baron \& Neuman, 1996; Hoel \& Cooper, 2000; O’Moore, Seigne, McGuire, \& Smith, 1998). Size of the organization (Einarsen \& Skogstad, 1996), the hierarchic (Ashforth, 1994, p. 761; Baillien, Neyens, \& De Witte, 2008) or horizontal (Spindel, 2008) nature of the organization, industrial structure 
(Einarsen \& Skogstad, 1996; Hoel \& Cooper, 2000; Salin, 2001), or the type and conditions of work (Baillien et al., 2008; Einarsen, Raknes, \& Matthiesen, 1994; O’Moore \& Lynch, 2007) were proposed as variables representing the causes of mobbing.

Organizational culture, climate, leadership are also seen as the catalysts of mobbing (Baillien et al., 2008; O’Moore \& Lynch, 2007). In organizations where mobbing is frequently observed, mobbing behaviors were permitted indirectly (Salin \& Hoel, 2011, p. 230), especially through the lack of sanctions while mobbing behavior is tolerated (Einarsen et al., 1994). On the other hand, ethical, participatory, and charismatic leadership styles in workplaces (Hauge, Skogstad, \& Einarsen, 2007; Stouten et al., 2010) were seen to be more successful in preventing mobbing.

\section{Outcomes of Mobbing}

Mobbing is a difficult experience for victims. Individuals experiencing mobbing are more stressed, anxious, depressive, aggressive, angry, and lonely (Mikkelsen \& Einarsen, 2001; Niedl, 1996; O’Moore et al., 1998; Vartia, 2001). Victims are also observed to experience more frequent physical and psychosomatic disorders such as headache and back pains, stomach and digestive track disorders, skin rash and other conditions, panic attack, sweating, shaking, eating disorders, pain, lethargy (Agervold \& Mikkelsen, 2004; Mikkelsen \& Einarsen, 2001; Niedhammer et al., 2009; Niedl, 1996; O’Moore et al., 1998) and burnout symptoms (Agervold \& Mikkelsen, 2004; Filizoz \& Ay, 2011). Mobbing is also a more significant cause of anxiety and depression in victims compared to other stress sources at the workplace (Hauge, Skogstad, \& Einarsen, 2010). Mobbing that leads to anxiety disorder in victims often results with post-traumatic stress disorder and even may reveal itself in extremes such as suicide (Leymann \& Gustafsson, 1996).

Mobbing is not only negative for its victims but also for the organizations. Furthermore, not only victims but also witnesses of mobbing are affected (Hoel \& Cooper, 2000). On many occasions, a single case of mobbing can cause a massive damage to an organization. Besides the formal costs of mobbing to organizations, inefficiency, loss of human capital, loss of organizational image, absences of personnel are some of other individuals exposed to mobbing have higher rates of absenteeism compared to other workers in many studies (Hoel \& Cooper, 2000; Niedl, 1996; Vartia, 2001). However, victims not always use their off days for sickness, and they may instead continue to work inefficiently (Caverley, Cunningham, \& MacGregor, 2007; Hoel \& Cooper, 2000).

The loss of qualified human capital, the decline in efficiency and absenteeism of employees effect not only organization but also the economy of the country (Rayner, Hoel, \& Cooper, 2002, pp. 59-60). Moreover, increases in health and insurance 
expenditures of victims, unemployment, and increase in the demand for support programs provided by the state, increase in early retirement can be listed as the harm caused by mobbing to the society and economy. Although some may underestimate the abovementioned harm viewing them as exaggeration, the study of Leymann (1996) shows how mobbing causes $30 \%$ to $50 \%$ of Sweden's early retirements.

\section{Research and Methodology}

\section{Descriptive Analysis of Mobbing in Higher Education}

Aim and Method. To reveal the big picture related to the mobbing experienced by faculty members, more research is needed both in Turkish and world literature. In this study, we aim to investigate the level and scope of the mobbing the faculty members are exposed to, and also to determine which types of mobbing behavior they are facing, by whom these behaviors are perpetrated, as well as age, gender, position, type of institution these faculty members serve for, and the duration of their employment. Moreover, our study particularly focuses on the victim reactions in response to the mobbing behavior as well as the social support from witnesses.

Sample. Based on Higher Education Council data, $45 \%$ of faculty members in Turkey work in Istanbul, Ankara, and Izmir, the three largest cities in Turkey. Our survey was conducted in these three cities with faculty member participants at junior ranks. Convenience sampling was employed in our study, and scholars from 51 universities with institutional e-mail addresses on the website of their affiliated universities were sent the link to an online survey to participate. In response to the 9898 questionnaires sent to invite participants, only 605 scholars responded to the survey (6.1\% return rate). A portion of participants was eliminated for the robustness regarding missing data, therefore, the final sample consisted 481 participants. Considering the sample characteristics, $70.7 \%$ of participants were research assistants, $29.3 \%$ were assistant professors. Looking at the locations of participants, $42.6 \%$ of them were from Istanbul, 32.4\% from Ankara, and 24.9\% from Izmir. While $68 \%$ of participants worked in public universities, $32 \%$ were from private universities. The rate of women participants was $60.9 \%$. In regards to the age distribution of participants, $15 \%$ of them were in 20-25 years old range, $37.6 \%$ were between 26 and 30 years old, $37.8 \%$ were between 31 and 40 years old, and $9.6 \%$ of them were above $41.43 \%$ of participants possessed a graduate degree, $40 \%$ of them had doctoral degrees, and $17 \%$ had undergraduate degrees. Also, $51.6 \%$ of participants had duration of work between 1 and 5 years, while $21.8 \%$ had work experience between 5 and 10 years, and $13.3 \%$ of them had more than 10 years of experience in the organizations they work for. $13.3 \%$ of the participants had less than one year and more than six months of experience in their affiliated institutions. 


\section{Measure}

Mobbing scale. The measure of the mobbing in this study was developed based on the WAR-Q scale of Neuman and Keashly (2004) and the NAQ-R scale of Einarsen et al. (2009). Since the working conditions in the university environment are different than other workplaces, it was decided to use a different measure. Content translated by three independent experts of English and Turkish and then were translated back into English by two experts again. Some expressions were eliminated or changed after the comparison of translations. Content validity was achieved by handing out the scale items to 10 academicians to understand whether the items were appropriate. Using the feedbacks of these experts, some items were deleted, because they were not found suitable for academic environment, and wording was changed for some others. Only after then, it was determined to use the scale for further analysis. A five-point Likert scale (never, occasionally, once a month, once a week, everyday) was used while asking participants how frequently they are exposed to mobbing behaviors, and if they are exposed who was the aggressor in most of the cases (superiors, peers, subordinates, students, administrative personnel, other).

Considering item-scale reliability statistics, factor loadings and relevance considerations, 31 items were decided as the final scale instrument. Cronbach $\alpha$ coefficient was found to be 0.96 . Factor analysis using VARIMAX rotation yielded four factors including behaviors targeting communication and social relationships, targeting personal reputation, targeting professional reputation and physical threats with a factor loading above 0.4 following Stevens (2009, p. 333). Also, construct validity of the developed mobbing scale was done through employing factor analysis to every item of all scales including social support scale and one other scale regarding mobbee responses. Nunnally (1984, p. 90) asserts that construct validity can be achieved by making sure the supposed measure(s) of the construct behave as expected in relation with other measures. Results showed that none of the items in different measures fell into another scales' factor loadings pointing out construct validity of mobbing scale and perceived social support scale.

Social Support Scale. The selected measure to assess the degree of perceived social support developed originally by Schwarzer and Schulz (2000) and adapted by MinibasPoussard and Idig-Camuroglu (2015). The 5-point Likert scale (5 items) was used to evaluate how much people are cared and supported in the mobbing process. Respondents were asked to evaluate the degree of their perceived support at work during the mobbing process. Scale yielded a high internal consistency (Cronbach $\alpha=0.94)$.

\section{Analysis and Results}

As part of the survey research, frequency of mobbing, general mobber profile, mobbees' reactions, social support, and victimization were analyzed. Using SPSS 
package, several analyses were conducted including frequency, correlation, regression analyses and independent samples t-tests, ANOVA and chi-square tests.

\section{General Evaluation of Mobbing}

Findings yielded the frequency of mobbing ranged between $5 \%$ and $81 \%$, however, this does not mean the level of mobbing is at $81 \%$. The criterion of mobbing broadly recognized by scholars and Leymann $(1990,1996)$ is "to be exposed to mobbing at least for six months period and at least once a week". We calculated in our study the sum of the ones exposed to mobbing (one mobbing behavior) at least once a week and every day for at least six months, which is at the level of $26 \%$. On the other hand, $3 \%$ of the employees have never experienced mobbing. The most frequent behaviors are giving inappropriate or meaningless tasks that are below the level of qualifications, not regarding the views or thoughts of the individual, giving overloaded tasks, disregarding the contributions, hiding information that may impact work performance, excessively inspecting/controlling the tasks, diffusing false rumors and gossips, giving unrealistic deadlines for hard to accomplish tasks. These 10 behaviors with the highest frequencies correspond to the factors targeting personal and professional reputation, they belong to the mobbing behaviors towards harming personal or professional esteem according to the categorization of Leymann (1996). All of the behaviors except the "diffusing false rumors" were related to the work. In the categorization of Einarsen et al. (2009) these behaviors also correspond to the mobbing behaviors toward work. The least frequent behaviors fit in the category representing behaviors threatening physical health according to the typology of Leymann (1996) such as blocking the way while walking and being threatened by physical harm.

Table 1

Percentages of Mobbing Behaviors

\begin{tabular}{lcccc}
\hline Mobbing behaviors & Occasionally & Once a month & Once a week & Everyday \\
\hline You are given tasks that are below your qualifications. & 43.2 & 10.2 & 15.8 & 10.4 \\
You are given meaningless tasks to carry out. & 47.8 & 12.7 & 11.4 & 8.9 \\
Your opinions are ignored. & 49.1 & 9.1 & 8.5 & 10 \\
You are given excessive workload. & 40.3 & 6.7 & 5.6 & 7.7 \\
Your contributions are ignored. & 38.7 & 7.7 & 2.5 & 8.7 \\
You are not given the necessary information that & 45.1 & 7.1 & 4.8 & 5.2 \\
affects your performance. & 35.6 & 6.4 & 5.4 & 6.9 \\
Your work is excessively monitored. & 36 & 6.4 & 2.9 & 8.3 \\
Gossips and rumors are spreaded about you. & 40.7 & 8.9 & 5.2 & 3.1 \\
You are given unreasonable deadlines. & 32.2 & 4.2 & 2.5 & 7.7 \\
You are forced not to claim the rights you are entitled. & & & \\
\hline
\end{tabular}

We compared research assistants $(\mathrm{N}=340)$ and assistant professors $(\mathrm{N}=141)$. We observed no significant difference depending on the level of exposure to mobbing. Regarding the factors of mobbing, no significant differences were observed between research assistants and assistant professors in terms of targeting communication and 
social relationships, targeting personal reputation and physical threats. However, research assistants reported higher levels of mobbing behavior targeting professional reputation $(\mathrm{t}=2.58, p \leq 0.01)$. Looking at the aggressor side, it can be seen that research assistants reported higher levels of mobbing behaviors compared to assistant professors in terms of being given lower-rank $(\mathrm{t}=4.92, p \leq 0.01)$, being given tasks that are beyond their personal capability or skills $(\mathrm{t}=2.46, p \leq 0.05)$, being asked to do meaningless tasks $(\mathrm{t}=5.71, p \leq 0.01)$, and being reminded of mistakes or criticized all the times $(\mathrm{t}=$ $2.87, p \leq 0.01)$. It was also observed that assistant professors reported higher levels of mobbing behaviors related to physical threats compared to research assistants.

Comparing academicians in private $(\mathrm{N}=327)$ and public universities $(\mathrm{N}=154)$, a significant difference between the employees was observed regarding mobbing behavior $(\mathrm{t}=2.49, p \leq 0.05)$. We found that academicians working in public universities $\left(\mu_{\text {public }}=54.20, \mathrm{sd}=21.51\right)$ were exposed to mobbing at higher levels compared to the ones $\left(\mu_{\text {private }}=49.58, \mathrm{sd}=17.65\right)$ working in private universities. Regarding of the factors of mobbing behavior, our comparison revealed a significance difference between private and public universities. Participants from public universities are exposed to mobbing at significantly higher levels regarding behaviors targeting individuals' communication and social relationships $(\mathrm{t}=3.59, p \leq 0.01)$ and targeting personal reputation $(\mathrm{t}=2.62, p \leq 0.01)$.

With regard to the general findings of mobbing behavior, it is measured that faculty members from public universities are more exposed to various types of mobbing behavior. These behaviors are: diffusing false rumors $(\mathrm{t}=2.41, p \leq 0.05)$, not giving permission or right for expression in meetings $(\mathrm{t}=2.88, p \leq 0.01)$, not inviting to meetings $(\mathrm{t}=3.59, p \leq 0.01)$, not talking with the mobbee during meetings $(\mathrm{t}=3.41$, $p \leq 0.01$ ), aggressive behavior to humiliate the individual with his/her private life, attitudes and personality $(\mathrm{t}=2.88, p \leq 0.01)$, being reminded about mistakes and criticisms continuously $(\mathrm{t}=3.18, p \leq 0.01)$, being exposed to bad jokes $(\mathrm{t}=2.01$, $p \leq 0.05)$, groundless accusations $(\mathrm{t}=2.41, p \leq 0.05)$, experiencing behavior that is humiliating $(\mathrm{t}=2.74, p \leq 0.01)$, spending effort to keep other workers to show these behaviors towards the mobbee $(\mathrm{t}=2.41, p \leq 0.05)$, refusing help requests to put the individual in hardship or difficulty $(\mathrm{t}=2.87, p \leq 0.01)$, consciously disrupting the work flow $(\mathrm{t}=2.30, p \leq 0.05)$, disregarding the contributions $(\mathrm{t}=2.55, p \leq 0.05)$, and being targeted by sudden anger explosions or verbal abuse $(\mathrm{t}=4.58, p \leq 0.01)$.

\section{Mobbers}

Results show that the aggressive behaviors most frequently experienced by participants as more than $80 \%$ are conducted by superiors. For both academic ranks, aggressive behaviors target social relations of the individual and try convincing peers to exercise these behaviors on the victim. While diffusing false rumors are mostly 
conducted by peers at the same rank level; physical threats or harmful behaviors also frequently come from colleagues and students. Generally, false rumors targeting individuals' esteem, humiliating and degrading behaviors, making groundless accusations, mocking, making humiliating or hostile comments about the personality, attitudes and private life are among the most observed mobbing behaviors. For assistant professors and research assistants, Table 2 shows the sources the mobbing behaviors come from.

Table 2

Percentages of Mobbers

\begin{tabular}{lcccc}
\hline Mobbing behaviors & Superiors & Colleagues & Administrative staff & Students \\
\hline You are given tasks that are below your qualifications. & 90 & 1.8 & 7 & 0.3 \\
You are given meaningless tasks to carry out. & 87 & 2.3 & 8.7 & 0.5 \\
Your opinions are ignored. & 88 & 8.9 & 1.9 & 0.3 \\
You are given excessive workload. & 94 & 1.7 & 3.1 & 0 \\
Your contributions are ignored. & 84 & 14 & 0.7 & 0 \\
You are not given the necessary information that & 70 & 22 & 5 & 0.7 \\
affects your performance. & 89 & 2.7 & 6.5 & 0.4 \\
Your work is excessively monitored. & 41 & 46 & 3.9 & 4.7 \\
Gossips and rumors are spreaded about you. & 90 & 1.4 & 8 & 0 \\
You are given unreasonable deadlines. & 90 & 0 & 7.6 & 0 \\
You are forced not to claim the rights you are entitled. & & & & \\
\hline
\end{tabular}

Participants were asked which gender group shows more aggressive behaviors, and $43.3 \%$ of participants reported that they were exposed to mobbing behavior by women, while $52.7 \%$ reported by men. Also, women reported that they are mobbed mostly by women $(71.2 \%)$, and men reported women as well, at the level of $52.7 \%$ $\left(\chi^{2}=11.55, p \leq 0.01\right)$.

\section{Mobbees' Reactions/Responses, Perceived Social Support}

Analyzing the reactions or responses to mobbing behavior, trying to remain distant to the aggressor (89\%), expecting a miracle (57\%), becoming introvert (49\%), and attempting to confront the mobber with anger (44\%) were common as emotionfocused reactions, while seeking individuals that can give ideas or advices $(82 \%)$ and looking for individuals to share emotions (87\%) in the workplace were common responses as part of social support seeking reactions. The least frequent response was to file an official complaint (12\%) against the mobbing behavior. Groups representing the lowest and highest exposure to mobbing are compared in relation to participants' responses. The difference is quantitative rather than qualitative. Both problem-oriented $(\mathrm{t}=17.33, p \leq 0.001)$ and emotion-oriented $(\mathrm{t}=6.40, p \leq 0.01)$ responses represented an increase in the mobbing frequencies.

With regard to gender, women responded to mobbing significantly more emotionoriented compared to men $(\mathrm{t}=1.97, p \leq 0.05)$. Women tended to feel themselves 
increasingly powerless or guilty and became more introverted $(\mathrm{t}=2.05, p \leq 0.05)$ and tried to remain distant to the aggressor $(\mathrm{t}=2.28, p \leq 0.05)$. Men filed official complaints at higher rates compared to women $(\mathrm{t}=-2.28, p \leq 0.05)$. In terms of the position, assistant professors have higher tendencies of reporting their experiences to senior management compared to research assistants $(\mathrm{t}=-4.43, p \leq 0.001)$, and they filed more official complaints as well $(\mathrm{t}=-2.56, p \leq 0.05)$. Besides, participants from public universities had higher tendencies of expecting a miracle $(\mathrm{t}=1.99, p \leq 0.05)$, while they also felt powerless and unable to act $(\mathrm{t}=2.00, p \leq 0.05)$. Participants with lower perceived social support showed significant differences from other groups, particularly in terms of emotion-oriented responses such as expecting a miracle $(\mathrm{t}=$ $2.64, p \leq 0.01)$, accusing self and feeling desperate $(\mathrm{t}=2.72, p \leq 0.01)$ and attempting to confront aggressors with anger $(\mathrm{t}=2.11, p \leq 0.05)$.

\section{Inductive Analysis of Case Narratives}

\section{Aim And Method}

Scholars have used case narratives as a medium of research previously (Bamberg, 2006; Brandell and Varkas, 2001; DeVilbiss, 2014; Marciniak, 2008; Riessman, 2005; Riessman, 2011), and Shkedi (2005) introduced multiple case narratives as a distinct approach, to overcome the limitations of both quantitative and qualitative research. We integrated the in-depth qualitative study of [multiple] case narratives as a followup to our quantitative survey analysis corresponding to what Creswell (2018) calls a sequential explanatory strategy, aiming to explain and to interpret quantitative results by collecting/analyzing qualitative data. Besides helping to observe unexpected variables in the quantitative model built (Morse, 2003), this strategy intends to overcome limitations of quantitative research serving as a concurrent triangulation strategy for confirmation, disconfirmation, cross-validation and corroboration (Cresswell, 2018).

To systematically analyze mobbing, we have built and analyzed in-depth multiple case study narratives with participants who decided to share their cases with us throughout our mobbing studies phase, and each case represents an observation with specific context, time period, conditions, causes, processes, and outcomes.

We have composed 19 case narratives from public universities of Istanbul and Ankara that are collected from 6 research assistants, 7 research assistants with a doctoral degree, 4 assistant professors who has been successfully passed the tenuretrack examination however not yet given their associate professor positions, and also 2 associate professors who despite their tenured scholarship are still in research assistant positions. Their ages are between 25 and 35, and 10 of them are women while 9 of them are men. Consecutive semi-structured interviews were conducted 
with participants throughout a period of 3 to 4 years, and in the aftermath of the first interviews, direct observations followed.

\section{Analysis and Findings}

The analysis of multiple case narratives is performed inductively under five categories that are mobbing behaviors (as to how), reasons/causes of mobbing, and the intention behind mobbing, social support, victims' reactions, and vicious cycle. Investigating how mobbing is realized, and what behaviors mobbees are exposed, similar findings were revealed in the analysis of case narratives such as excessive work load, assigning impossible to finish tasks, assigning irrelevant tasks below the level of academic qualification, pressure to suppress demands of rights, dismissing successes and contributions, diffusing false rumors.

A participant said: "I was tenured to associate professor, however, I was still in the position of research assistant officially which is why I was even obliged to manage the exams of faculty members without doctoral degrees." Another faculty said: "As a research assistant at the beginning of my graduate degree, I was grading exam papers of ten courses. Professors were continuously criticizing my performance and when I told them I don't have sufficient time left for research because of the heavy work load, they accused me of being insufficient." Moreover, other have expressed more conflictive scenes such as: "To avoid me having courses to teach, department chair was diffusing false rumors claiming that my teaching was bad while also seemingly blocking students' official complaints to demonstrate protective behavior." or "I am continuously given courses that are out of my expertise so that I can't successfully teach. Positive feedback from students taking my courses in my expertise area is dismissed. They even went so far to hire another associate faculty to give my doctoral courses. I was informed about this new hire while I was teaching a course."

In addition to the abovementioned pieces from narratives, the following ones are other good examples of suppressed rights, accusations, and arbitrary decisions at institutional settings, such: "Each time I went to demand my official position for an assistant professor, I was either avoided or accused. They told: 'Spend your time to write and publish research. All of your publications have three or four co-authors. How can we know you have completed them?' However, most of these publications were of international high quality (SSCI) research." or even sexual demands and diffusing false rumors, such as: "I had a short-term relation with a professor from the department. When I told I want to break up, mobbing started. He discredits my performance everywhere. He diffused false rumors claiming that my doctoral thesis is completed by someone else and that I gave students the questions of the exams." 
Mobbers were mostly superiors. In collective mobbing at the level of colleagues, senior administration was also present or somehow approved mobbing, such as the following narrative: "Two colleagues I was sharing my office with particularly one of them, showed me hostile attitudes and cut off our communication except for required moments. I was feeling they were manipulating people against me, including the department chair who was easy to manipulate and was afraid of losing his position. Despite our previous positive communication, chair started to yell at me and making me anxious. I found out he decided to change my office during my off days." or another one: "After completing my doctorate, I could not get my tenure for a long time. I found out some faculty members were trying to avoid my tenure. They were older than me but with no doctorate, and they viewed themselves as my superior. When I talked to the department chair during my tenure, he mumbled that there is no open position." Another narrative shows the collective involvement at institutional level: "I remained nine months away from university when I was diagnosed with breast cancer. When I returned back to work I found a scene more destructive than cancer. My desk was given to someone else, and my belongings were packed into a storage. Their reaction was: 'we thought you would not return back. 'My colleagues blamed the administration which blamed my colleagues, and this situation went on for many months."

Out of the analysis of 19 case narratives throughout the course of our research, the question as to whether mobbing is an objective or a tool sparked our interest, as mobbing was so often observed to occur while violating employee's individual and collective rights. We observed that being denied from employee rights emerged as the most important cause of mobbing, but also as the process and outcome of mobbing, as can be seen in the narrative including: "Despite four years have passed after my tenure as an associate professor, I still was not given my official position. First, I was told no position was available, then, assignment criteria were heightened. Most of my international publications have co-authors. Despite I have two book publications, I was asked to have a single author book."

In another representative narrative, participant expressed: "Although I completed my doctorate and I had enough publications, I could not get my assistant professor position. I knew department chair was avoiding, and in my interviews with vice presidents of the university, I was told there are no positions available. They told me to get my tenure to associate professor and they will directly assign my position to associate faculty level. I dedicated myself to my work and passed associate tenure exam. However, they still did not give me my position, and I kept working for years as a research assistant although I was a tenured faculty member."

The second most significant mobbing behavior was to be covertly suspended from scholarly duties and contributions, such as being excluded from thesis committees 
or research and teaching duties, as can be seen in the following narrative: "Despite I was associate faculty, I was not given any doctoral courses to teach nor thesis adviser tasks. As a reason, I was being told there is no student studying in my expertise area. However, department chair was manipulating students about what to study."

The following one: "I was teaching courses of other professors when I was a research assistant. When I was tenured to assistant professor, I was directed to teach service courses taught in other departments despite I am able to teach many courses in my own department."

The third important mobbing behavior is to delay or avoid doctoral dissertation processes, expressed in narrative as: “My master's thesis defense was constantly avoided. My thesis adviser wanted to have an intimate relation with me but I refused. He was not permitting me to replace my thesis adviser."

Another narrative was: "My doctoral thesis was continuously delayed. My adviser was always asking me to change something or add. When his demands were inappropriate, I realized it was intentional blocking. "

We determined victims were able to realize the reasons for mobbing in longitudinal period throughout the process. Expressed reasons were interests/benefits, favoritism, rivalry, proof of power, not kneeling down, personal hatred or jealousy, demands for sexual relations, political or religious beliefs. In many cases, mobbing was reflected as an outcome of power show-off, as expressed by participants, such as: "Department chair was protecting his seat with personal relationships. His knowledge was remaining from the 90s, and he was not able to update himself, not publish research. If I taught in the department, it would reveal his deficiencies."

Another participant stated: "Department chair wanted to co-author a book. More correctly put, he wanted me to put his name in first on the book while I write it. I did not start this project and avoided it. Then, mobbing started. He spent every possible effort to show he possessed the power."

A participant, for instance, was not given his tenured affiliation because of political thoughts, and another for his religious sect while in other instances, superiors (mostly department chairs) had personal stake, expressed as: "Department chair wanted me to approve a master's thesis although it was not at good one. I found out that the student was his friend'. I did not approve the thesis because it did not merit. He started to avoid my phone calls, and not informing me about the meetings. He refused all of my demands in the aftermath, and initiated somewhat a war of power."

In another case, participant expressed: "I realized the reason for the delay of my doctorate later. The wife of department chair was a doctoral candidate too, and there was only one assistant professor position." Scope of mobbing went to higher ranks, 
expressed as: "He was manipulating university president, vice-president, deans and he was delaying assignment processes of the ones who did not vote for him. Even in the ones who voted for him were not meeting the publication criteria, they did not experience assignment problems."

Being refused for intimacy was another cause, expressed as: "My superior wanted an intimate relationship with me, and I refused and distanced myself. He started to tell stories as if he has been with me and he left me in the aftermath, and that is why I behave him bad. He even went further and started to diffuse rumors that I had intimate encounters with an elder faculty member whom I view as my brother."

Investigating how victims react or respond and how they enter into a vicious cycle, we observed that accusing the other side, suffocating witnesses when trying to convince them, and constantly focusing on the event of mobbing and also the feeling of shame and guilt emerge as the most important factors, seen in following narrative pieces: "When I reminded the tenure criteria applied in the faculty where president's daughter and niece work, the criteria for my tenure was even heightened more. They declared my co-authored book invalid for my tenure."

"My department chair views he is rightful when he yells at me when things don't go the way he wants. Shouting on, humiliating, insulting, threatening to fire and doing all of these in front of others is a norm for him. After a tough year, when I attempted to defend myself against the accusation, he declared the grand victory of telling me that he won't renew my contract. Everybody is afraid of him and were blaming me. I was angry with my colleagues. At the end I was alone, and even the daily information were no more told to me."

Regarding how the emotion-reflection-behavior chain leads the situation into a vicious cycle at individual level, other narratives revealed responses more substantially, such as: "When I left work in the evenings, I kept fighting with the department chair and the dean in my mind. I was unable to sleep most of the time and I was having difficulties waking up in the morning to go to work."

A participant expressed: "My superior was always trying to find my mistakes to hide his own deficiencies. At the beginning, I was somehow reacting and was proving I am right. In time, I started to doubt myself. I was not sure, and I was controlling again and again, and I was worried. I lost my speed, and I totally lost my self-confidence."

As well as the following narrative revealing shame of self or guilt: "When Idefended my rights, I was put in the guilty position at my workplace, and other colleagues accused me of being reactive I was feeling like a loser as if I was unsuccessful in handling all of this situation. I was constructing responses in my mind when I was going for new job interviews in case they may ask me why I want to leave my job, and that was a source of shame." 
Victims expressed that the insensitivity of the people around is a factor making coping and tolerance more difficult in the already tough process, such as the narratives expressing: "When our dean was asking me something or thanking me, he was wrapping around my neck, kissing, holding my hands. I was pulling myself away. I try to reproduce pretexts to not go to his office. But I am his assistant and I can't completely be distant. Other women colleagues are also complaining, but they are able to distant themselves since they only see each other in corridors. I asked help from a few women colleagues since I felt myself close to them, and they reported to management and even expressed they are disturbed too. Management responded that they can't do anything since he is a senior and it is his way of communication with others. Later, I heard people saying I exaggerated the situation."

A participant said: "Department chair was always threatening me with firing me and blocking my future. Everybody was remaining distant to me since they were afraid of him, including my best friend whom I helped to get hired. Once, I was told by my friend that he perceived us same, and called her with my name once, after which my friend became distant, and even was not disturbed of being assigned my tasks."

Another participant expressed: "Department chair developed hostility towards me because I did not do his personal tasks (buying concert tickets and putting conference posters). For the smallest issue in my performance, he would be tough on me. Other faculty members and colleagues were telling how they felt sorry. They would criticize department chair for his behavior, but would never give the same reactions next to him after they would not go to lunch with me to not to be seen with me, and they would not invite me when they meet out of the work."

If social support does not become substantial but remains only verbal, it is not impactful. Because it is viewed as disingenuous and hypocritical. Many mobbees have expressed the most impactful social support came from family members and closest circles such as: "What helped me to survive was my family and close friends. The support of my colleagues was an empty solace." or "I was unemployed when I was continuing my doctorate at another university. My family spent all their savings for me to complete my doctorate. This helped me to avoid being stuck in the past."

Exploring how one is out of the vicious cycle and how solutions are found, we observed that the best solution was to get away from the mobbing environment, expressed as: "I waited for my associate tenure for years. I found a position at another university in another city easily. In two years, I even became the vice dean. Although I heard they decreased the criteria in my previous university which made me sad, I just kept advancing on my new path. "

Another participant's solution was: "I kept working as a research assistant after completing my doctorate. My application for an assistant professor position at foreign 
university was accepted. My intent was to stay in Turkey. When I met with department chair I was told there is no position. Three months later, a friend of department chair was given assistant professor position."

A participant told: "I completed my doctorate and returned to Turkey. Department chair was avoiding my assistant professor position. Because I did not let him get closer to me. At the end, I decided to work in private industry. I keep giving courses in management departments of universities and joining conferences. But I don't consider to return to university anymore."

Victims have expressed they felt empowered when they decided to quit the work environment where mobbing is present. Success in other workplaces is identified as the best response to the previous organization. In all of the case narratives, unique mechanisms of coping and resilience building were expressed by the mobbees, although many of them still keep having anger, frustration, and injustice towards the mobbing perpetrated by their superiors at their previous workplace. Feelings such as worthlessness, depression, and powerlessness were also present in observations. A particularly difficult factor was that the senior management has protected the mobber instead of the victims of mobbing. Another question that emerged from the case narratives was: What eventually helps them to get out of the vicious cycle is to shift from "What did I do to deserve this?" thought to "I did not deserve this" stance. Finding opportunities in their new universities, and notably obtaining their tenures were seen to help them a great deal to recover from the impact of mobbing they were exposed to.

\section{Discussion}

In the quantitative study, we aimed at observing the types and frequency of mobbing experienced by research assistants and assistant professors in private and public universities. Our research is grounded on the "at least during six months and at least once a week" criteria of Leymann (1990, 1996), and mobbing was measured to react to $26 \%$. In similar studies in the Western European contexts based on the same criteria, this rate is around $10 \%$ to $14 \%$ (Hoel et al., 2001; Mikkelsen \& Einarsen, 2001; Niedhammer et al., 2009; Zapf, Escartin, Einarsen, Hoel, \& Vartia, 2011). In their similar study with various industries in Turkey, Minibas-Poussard and Idig-Camuroglu (2016) have measured a rate around $23 \%$ for mobbing. The level of mobbing exposure experienced by scholars in academia is higher than the level of mobbing experienced in other workplaces. This finding corresponds with the study of Keashly and Neuman (2010). When we look at the other studies in Turkey, mobbing frequency was found to range between 11.6\% and 70\% (Apaydin, 2012; Cogenli \& Asunakutlu, 2016; Gul et al., 2011; Tanoglu et al., 2007; Yelgecen-Tigrel \& Kokalan, 2009). 
The most frequently experienced mobbing behaviors are to be given meaningless tasks below the level of qualification, to be dismissed when sharing thoughts or ideas, to be given heavy load of impossible to complete tasks, to be disregarded for contributions, to be hidden from information that can impact performance, excessive control or inspection of tasks being done, diffusing false rumors and gossips, to be given tasks with impossible to catch deadlines, and to be put pressure on to not demand rights. These are mostly mobbing behaviors towards damaging victim's personal or professional reputation. Keashly and Neuman (2013) have expressed that mobbing in universities reveals itself in the form of exclusion, blocking or threatening professional esteem. Celep and Konakli (2013) reported that academics are threatened with their work performances, personal characteristics/values, and right for building relationship and communication. Cemaloglu and Sahan (2013) also reported that mobbing in universities occur with blocking one's rights and not letting him/her teach courses, blocking scholar's academic advancement and research, hiding information, putting pressure on, diffusing false rumors, excluding from the group, making feel the mobbee worthless, continuous inspection and control over mobbee. Yelgecen-Tigrel and Kokalan (2009) added being given meaningless tasks, scientific ideas being stolen, disregarding efforts, and not letting know about the meetings.

Mobbing behaviors were mostly committed by the superiors, ranging between $41 \%$ and $93 \%$, and between peers at $50 \%$. Others reported similar results confirming the mobbing committed by superiors (Einarsen et al., 1994; Gunel, 2010; MinibasPoussard \& Idig-Camuroglu, 2016; Rayner, 1997; Seckin-Halac \& Bulut, 2010; Tanoglu et al., 2007; Zapf et al., 2011). Moreover, mobbing emerges between peer levels as well (Keashly \& Wajngurt, 2016). Most of the mobbing behaviors targeted victim's professional prestige are committed by superiors, while mobbing targeted mobbee's social relations were committed by peers. Both superiors and peers have also commonly committed mobbing related to personal reputation by diffusing false rumors, showing humiliating behavior about victim's personal life and characteristics, making destructive and aggressive comments.

While some mobbing behaviors are observed to be different, there is not a significant relationship between affiliation/title, gender, age and being exposed to mobbing in general. In many studies, age (Bilgel, Aytac, \& Bayram, 2006; Vartia, 1996), gender (Hoel \& Cooper, 2000; Tanoglu et al., 2007) and affiliation/title (Tanoglu et al., 2007; Yelgecen-Tigrel \& Kokalan, 2009) were found to be insignificant regarding mobbing. On the other hand, our study found that participants from public universities were exposed significantly more mobbing than private universities'. Although some previous studies support this finding about the prevalence (Civilidag, 2011; Gunel, 2010; Salin, 2001), there are also studies indicating vice versa (Einarsen \& Skogstad, 1996; Yildirim \& Yildirim, 2007). The reason behind the frequency and level of 
mobbing in public universities can be explained with the limitations of officially opened positions for faculty in departments, and the relatively higher job security compared to private institutions. The only way to fire a faculty from public universities is to make them resign with their own consent. Therefore, the unwanted faculty is pushed to resignation to leave the university. In the analysis of case narratives, mobbing behavior repeatedly represented by victims was being precluded from their legal rights. In some cases, mobbing is even an element of a hidden agenda, a means for favoritism, since positions emptied by resigned faculty may be given to relatives or friends, a primary motive for the mobber to commit mobbing as a strategy. Besides favoritism, personal hatred, hostility, the difference in political or religious thoughts may also represent the causes of mobbing. The analysis of narratives leads us to think how mobbing can gain an institutional dimension when tolerated or enforced by the administration, although they first start as an interpersonal conflict. Managers need to be aware of the conflicts within the workplaces and take necessary precautions to solve the problems before they turn into mobbing. Ignoring such behaviors and weak managerial interventions can deepen the conflicts, and deteriorate the organizational culture (Einarsen et al., 1994). Future research will investigate how interpersonal conflicts can lead to mobbing if tolerated by the management.

Structural and systemic dynamics are clearly seen to play an important role in mobbing. Narratives clearly showed that personal conflicts between two employees could easily turn into organizational mobbing by spreading through fear and retaliation. The lack of sanctions both in the organization and higher bodies give rise to the frequency of mobbing. Keashly and Wajngurt (2016) have discussed the reason of mobbing and made suggestions on two major factors: Integrity between policy and implications, and peer impact in struggling against mobbing. Some scholars have emphasized the ethical infrastructure in organizations to fight against mobbing (Einarsen, Mykletun, Einarsen, Skogstad, \& Salin, 2017) while others highlighted the importance of diagnosis with the help of peers (Lewis, 2013). Both university administrations and also the higher authorities such as the Higher Education Council in Turkey have to adopt responsive policies to fight against mobbing. Also, training in universities teaching employees about what is mobbing, what cannot be accepted, and what can be done when faced with mobbing must be in place.

Similar to other complex social phenomena, research on mobbing is rigorous as interpersonal and organizational conflict impact observations and self-perceptions, as well as the relational power status within and beyond institutions. Our study is a substantial step towards developing our understanding over mobbing in higher education, as we adopted a mixed method approach to deepen the exploratory and descriptive nature of our research. In that sense, not only the various important variables and details gained significance in our in-depth narrative inquiry such as conflict, management practices, and 
organizational policy, but also we were able to test the findings of our quantitative model. While our study is a substantial step in mobbing research in the particular context of Turkey, we acknowledge the limitations of our study, and further research can overcome these limitations by improving the sample size of our quantitative model to improve reliability and control data robustness, while additional in-depth cases eventually will help to strengthen the overall validity of our findings.

\section{References}

Agervold, M., \& Mikkelsen, E. G. (2004). Relationships between bullying, psychosocial work environment and individual stress reactions. Work \& Stress, 18(4), 336-351. https://dx.doi.org/ 10.1080/02678370412331319794

Ahmad, S., Kalim, R., \& Kaleem, A. (2017). Academics' perceptions of bullying at work: Insights from Pakistan. International Journal of Educational Management, 31(2), 204-220. https:// dx.doi.org/10.1108/IJEM-10-2015-0141

Apaydin, C. (2012). Relationship between workplace bullying and organizational cynicism in Turkish public universities. African Journal of Business Management, 6(34), 9649-9657. http:// dx.doi.org/10.5897/AJBM12.800

Ashforth, B. (1994). Petty tyranny in organizations. Human Relations, 47(7), 755-778. http:// dx.doi.org/10.1177/001872679404700701

Baillien, E., Neyens, I., \& De Witte, H. (2008). Organizational, team related and job related risk factors for workplace bullying, violence and sexual harassment in the workplace: A qualitative study. International Journal of Organizational Behaviour, 13(2), 132-146.

Bamberg, M. (2006). Stories: Big or small: Why do we care?. Narrative Inquiry, 16(1), 139-147. http://dx.doi.org/10.1075/ni.16.1.18bam

Baron, R. A., \& Neuman, J. H. (1996). Workplace violence and workplace aggression: Evidence on their relative frequency and potential causes. Aggressive Behavior, 22(3), 161-173. http:// dx.doi.org/10.1002/(SICI)1098-2337(1996)22:3<161::AID-AB1>3.0.CO;2-Q

Bilgel, N., Aytac, S., \& Bayram, N. (2006). Bullying in Turkish white-collar workers. Occupational medicine, 56(4), 226-231. https://dx.doi.org/10.1093/occmed/kqj041

Bowling, N. A., Beehr, T. A., Bennett, M. M., \& Watson, C. P. (2010). Target personality and workplace victimization: A prospective analysis. Work \& Stress, 24(2), 140-158. https://dx.doi. org/10.1080/02678373.2010.489635

Brandell, J. R., \& Varkas, T. (2001). Narrative case studies. The Handbook of Social Work Research Methods, 293-307. http://dx.doi.org/10.4135/9781412986182

Caverley, N., Cunningham, J. B., \& MacGregor, J. N. (2007). Sickness presenteeism, sickness absenteeism, and health following restructuring in a public service organization. Journal of Management Studies, 44(2), 304-319. http://dx.doi.org/10.1111/j.1467-6486.2007.00690.x

Celep, C., \& Konakli, T. (2013). Mobbing experiences of instructors: Causes, results, and solution suggestions. Educational Sciences: Theory and Practice, 13(1), 193-199.

Cemaloglu, N., \& Sahan, G. (2013). Akademisyenlerin üniversitelerde karşılaştıkları mobbing ve başa çıkma yolları [Mobbing academicians face within universities and their coping styles]. Proceedings of II. Kamu Etiği Kongresi. TODAIE - Publication No: 383. 
Civilidag, A. (2011). Üniversitelerdeki öğretim elemanlarının psikolojik taciz (mobbing), iş doyumu ve algilanan sosyal destek düzeyleri [Mobbing, job satisfaction and perceived social support levels of academic staff in universities] (Master's thesis, Selçuk University, Konya, Turkey). Retrieved from https://tez.yok.gov.tr/UlusalTezMerkezi/

Cogenli, M. Z., \& Asunakutlu, T. (2016). Akademide mobbing: Adım Üniversiteleri Örneği [Mobbing in academia: An investigation at adım universities]. Erzincan Üniversitesi Sosyal Bilimler Enstitüsü Dergisi, 9(1), 17-32.

Creswell, J. W. (2018). Research design: Qualitative, quantitative, and mixed methods approaches (5th ed.). Sage publications: Los Angeles.

DeVilbiss, J. M. (2014). Narrative case studies exploring homelessness and education (Doctoral dissertation, University of Missouri-Kansas City).

Einarsen, K., Mykletun, R. J., Einarsen, S. V., Skogstad, A., \& Salin, D. (2017). Ethical Infrastructure and Successful Handling of Workplace Bullying. Nordic Journal of Working Life Studies, 7(1), 37-54.

Einarsen, S. 1, Hoel, H., Zapf, D., \& Cooper, C. L. (2011). The concept of bullying and harassment at work: The european tradition. In S. Einarsen, H. Hoel, D. Zapf, \& C. Cooper (Eds.), Bullying and harassment in the workplace: Developments in theory, research, and practice (2nd ed., pp. 3-40). Boca Raton, FL: CRC Press.

Einarsen, S., \& Mikkelsen, E. G. (2003). Individual effects of exposure to bullying at work. In S. Einarsen, H. Hoel, D. Zapf \& C. L. Cooper (Eds.), Bullying and harassment in the workplace: Developments in theory, research, and practice (pp. 127-144). London, UK: Taylor \& Francis.

Einarsen, S., \& Skogstad, A. (1996). Bullying at work: Epidemiological findings in public and private organizations. European Journal of Work and Organizational Psychology, 5(2), 185201. https://dx.doi.org/10.1080/13594329608414854

Einarsen, S., Hoel, H., \& Notelaers, G. (2009). Measuring exposure to bullying and harassment at work: Validity, factor structure and psychometric properties of the Negative Acts QuestionnaireRevised. Work \& Stress, 23(1), 24-44. http://dx.doi.org/10.1080/02678370902815673

Einarsen, S., Raknes, B. R. I., \& Matthiesen, S. B. (1994). Bullying and harassment at work and their relationships to work environment quality: An exploratory study. European Journal of Work and Organizational Psychology, 4(4), 381-401. https://dx.doi.org/10.1080/13594329408410497

Filizoz, B., \& Ay, A. F. (2011). Örgütlerde mobbing ve tükenmişlik olgusu arasındaki ilişkilere yönelik bir araştırma [A research on the relationships between mobbing and burnout phenomenon in organizations]. E-Journal of New World Sciences Academy, 6(2), 229-241.

Glasø, L., Matthiesen, S. B., Nielsen, M. B., \& Einarsen, S. (2007). Do targets of workplace bullying portray a general victim personality profile?. Scandinavian Journal of Psychology, 48(4), 313319. http://dx.doi.org/10.1111/j.1467-9450.2007.00554.x

Gul, H., Ince, M., \& Ozcan, N. (2011). The relationship between workplace mobbing and burnout among academics at a Turkish university. Research Journal of International Studies, 18(1), 118-134.

Gunel, Ö. D. (2010). İşletmelerde yıldırma olgusu ve yıldırma mağdurlarının kişilik özelliklerine ilişkin bir araştırma [Mobbing in organizations and a research on mobbing victims' personality characteristics]. Dokuz Eylül Üniversitesi Sosyal Bilimler Enstitüsü Dergisi, 12(3), 37-65.

Hauge, L. J., Skogstad, A., \& Einarsen, S. (2007). Relationships between stressful work environments and bullying: Results of a large representative study. Work \& Stress, 21(3), 220242. https://dx.doi.org/10.1080/02678370701705810 
Hauge, L. J., Skogstad, A., \& Einarsen, S. (2009). Individual and situational predictors of workplace bullying: Why do perpetrators engage in the bullying of others?. Work \& Stress, 23(4), 349-358. https://dx.doi.org/10.1080/02678370903395568

Hauge, L. J., Skogstad, A., \& Einarsen, S. (2010). The relative impact of workplace bullying as a social stressor at work. Scandinavian Journal of Psychology, 51(5), 426-433. http://dx.doi. org/10.1111/j.1467-9450.2010.00813.x

Hoel, H., \& Cooper, C. L. (2000). Destructive conflict and bullying at work. Unpublished report, Institute of Science and Technology, University of Manchester (UMIST). Retrieved from http:// www.adapttech.it/old/files/document/19764Destructiveconfl.pdf

Hoel, H., Cooper, C. L., \& Faragher, B. (2001). The experience of bullying in Great Britain: The impact of organizational status. European Journal of Work and Organizational Psychology, 10(4), 443-465. https://dx.doi.org/10.1080/13594320143000780

Keashly, L., \& Neuman, J. H. (2008). Workplace Behavior (Bullying) Project Survey. Minnesota State University, Mankato. Retrieved from https:/www.mnsu.edu/csw/workplacebullying/ workplace_bullying_final_report.pdf

Keashly, L., \& Neuman, J. H. (2010). Faculty experiences with bullying in higher education: Causes, consequences, and management. Administrative Theory \& Praxis, 32(1), 48-70. http:// dx.doi.org/10.2753/ATP1084-1806320103

Keashly, L., \& Neuman, J. H. (2013). Bullying in academia: What does current theorizing and research tell us?. In J. Lester (Ed.), Workplace Bullying in Higher Education (pp. 1-22). New York, NY: Routledge.

Keashly, L., \& Wajngurt, C. (2016). Faculty bullying in higher education. Psychology and Education - An Interdisciplinary Journal, 53(1-2), 79-90.

Lewis, D. (2003). Voices in the social construction of bullying at work: Exploring multiple realities in further and higher education. International Journal of Management and Decision Making, 4(1), 65-81. https://dx.doi.org/10.1504/IJMDM.2003.002489

Leymann, H. (1990). Mobbing and psychological terror at workplaces. Violence and Victims, 5(2), $119-126$.

Leymann, H. (1996). The content and development of mobbing at work. European Journal of Work and Organizational Psychology, 5(2), 165-184. https://dx.doi.org/10.1080/13594329608414853

Leymann, H., \& Gustafsson, A. (1996). Mobbing at work and the development of post-traumatic stress disorders. European Journal of Work and Organizational Psychology, 5(2), 251-275. https://dx.doi.org/10.1080/13594329608414858

Lind, K., Glaso, L., Pallesen, S., \& Einarsen, S. (2009). Personality profiles among targets and nontargets of workplace bullying. European Psychologist, 14(3), 231-237. http://dx.doi. org/10.1027/1016-9040.14.3.231

Lutgen-Sandvik, P., Tracy, S. J., \& Alberts, J. K. (2007). Burned by bullying in the American workplace: Prevalence, perception, degree and impact. Journal of Management Studies, 44(6), 837-862. http://dx.doi.org/10.1111/j.1467-6486.2007.00715.x

Marciniak, L. (2008). Multiple Case Narrative. Qualitative Sociology Review, 4(1), 232-233.

McKay, R., Arnold, D. H., Fratzl, J., \& Thomas, R. (2008). Workplace bullying in academia: A Canadian study. Employee Responsibilities and Rights Journal, 20(2), 77-100. http://dx.doi. org/10.1007/s10672-008-9073-3 
Mikkelsen, E. G., \& Einarsen, S. (2001). Bullying in Danish work-life: Prevalence and health correlates. European Journal of Work and Organizational Psychology, 10(4), 393-413. http:// dx.doi.org/10.1080/13594320143000816

Minibas-Poussard, J., \& Idig- Camuroglu, M. (2015). Psikolojik taciz iş yaşamında gerilim [Psychological harassment tension in the worklife]. Ankara, Turkey: Akılçelen Kitaplar.

Minibas-Poussard, J., \& Idiğ-Çamuroğlu, M. (2016). Mobbing in a cross-sectional national sample: The Turkish case. Australian Journal of Business and Management Research, 5(6), 24-34.

Morse, J. M. (2003). Principles of mixed methods and multimethod research design. Handbook of mixed methods in social and behavioral research, 1, 189-208.

Neuman, J. H., \& Keashly, L. (2004, April). Development of the workplace aggression research questionnaire (WAR-Q): Preliminary data from the workplace stress and aggression project. In R. J. Bennett \& C. D. Crossley (Chairs), Theoretical advancements in the study of antisocial behavior at work. Symposium conducted at the meeting of the Society for Industrial and Organizational Psychology, Chicago, IL.

Niedhammer, I., David, S., Degioanni, S., Drummond, A., Philip, P., \& 143 Occupational Physicians. (2009). Workplace bullying and sleep disturbances: Findings from a large scale cross-sectional survey in the French working population. Sleep, 32(9), 1211-1219.

Niedl, K. (1996). Mobbing and well-being: Economic and personnel development implications. European Journal of Work and Organizational Psychology, 5(2), 239-249. http:// dx.doi.org/10.1080/13594329608414857

Nunnally, J. C. (1984). Psychometric theory (3rd ed.). New York, NY: McGraw-Hill.

O’Moore, M., Seigne, E., McGuire, L., \& Smith, M. (1998). Victims of workplace bullying in Ireland. The Irish Journal of Psychology, 19(2-3), 345-357. https://dx.doi.org/10.1080/03033 910.1998.10558195

O’Moore, M., \& Lynch, J. (2007). Leadership, working environment and workplace bullying. International Journal of Organization Theory and Behavior, 10(1), 95-117.

Persson, R., Hogh, A., Hansen, Å. M., Nordander, C., Ohlsson, K., Balogh, I., ... Ørbæk, P. (2009). Personality trait scores among occupationally active bullied persons and witnesses to bullying. Motivation and Emotion, 33(4), 387-399. http:/dx.doi.org/10.1007/s11031-009-9132-6

Raskauskas, J. (2006, April). Bullying in academia: An examination of workplace bullying in New Zealand Universities. Paper presented at the annual meeting of American Educational Research Association, San Francisco.

Rayner, C. (1997). The incidence of workplace bullying. Journal of Community \& Applied Social Psychology, 7(3), 199-208. http://dx.doi.org/10.1002/(SICI)1099-1298(199706)7:3<199::AIDCASP418>3.0.CO;2-H

Rayner, C., Hoel, H., \& Cooper, C. (2002). Workplace bullying: What we know, who is to blame and what can we do?. London, UK: Taylor \& Francis.

Riessman, C. K. (2005). Narrative analysis. Huddersfield: University of Huddersfield.

Riessman, C. K. (2011). What's different about narrative inquiry? Cases, categories and contexts. Qualitative Research, 3, 310-330.

Salin, D. (2001). Prevalence and forms of bullying among business professionals: A comparison of two different strategies for measuring bullying. European Journal of Work and Organizational Psychology, 10(4), 425-441. http://dx.doi.org/10.1080/13594320143000771 
Salin, D. (2003). Ways of explaining workplace bullying: A review of enabling, motivating and precipitating structures and processes in the work environment. Human Relations, 56(10), 1213-1232. http://dx.doi.org/10.1177/00187267035610003

Salin, D., \& Hoel, H. (2011). Organisational causes of workplace bullying. In S. Einarsen, H. Hoel, D. Zapf, \& C. L. Cooper (Eds.), Bullying and harassment in the workplace: Developments in theory, research and practice (2nd ed., pp. 227-244). London, UK: Taylor \& Francis.

Schwarzer, R., \& Schulz, U. (2000). Berlin social support scales. Retrieved from www.ralfschwarzer.de

Seckin-Halac, D., \& Bulut, C. (2010, November). Remobbing: A review of Turkish literature. In A. Jezovnik (Ed.), Proceeding of the 11 ${ }^{\text {th }}$ Management International Conference: Social Responsibility, Professional Ethics, and Management (pp. 223-246). Ankara, Turkey.

Shkedi, A. (2005). Multiple case narrative: A qualitative approach to studying multiple populations. Amsterdam: John Benjamins Publishing Company.

Spindel, P. (2008). Psychological Warfare at Work. Toronto: Spindel \& Associates.

Stevens, J. P. (2009). Applied multivariate statistics fort he social sciences (5th ed.). New York, NY: Routledge.

Stouten, J., Baillien, E., Van den Broeck, A., Camps, J., De Witte, H., \& Euwema, M. (2010). Discouraging bullying: The role of ethical leadership and its effects on the work environment. Journal of Business Ethics, 95, 17-27. http://dx.doi.org/10.1007/s10551-011-0797-x

Tanoglu, Ş. Ç., Aricioglu, M. A., \& Kocabas, M. (2007). Research on mobbing in organizations: A case study on academicians. In H. Elwany \& A. B. Eltawil (Eds.), Proceedings of the 37th International Conference on Computers and Industrial Engineering (pp. 558-568). Alexandria, Egypt.

Vartia, M. (1996). The sources of bullying-psychological work environment and organizational climate. European Journal of Work and Organizational Psychology, 5(2), 203-214. https:// dx.doi.org/10.1080/13594329608414855

Vartia, M. A. (2001). Consequences of workplace bullying with respect to the well-being of its targets and the observers of bullying. Scandinavian Journal of Work, Environment \& Health, 27(1), 63-69. http://dx.doi.org/10.5271/sjweh.588

Yelgecen-Tigrel, E., \& Kokalan, O. (2009). Academic mobbing in Turkey. World Acedemy of Engineering, Science and Technology, 55, 963-971.

Yildirim, A., \& Yildirim, D. (2007). Mobbing in the workplace by peers and managers: Mobbing experienced by nurses working in healthcare facilities in Turkey and its effect on nurses. Journal of Clinical Nursing, 16(8), 1444-1453. http://dx.doi.org/10.1111/j.1365-2702.2006.01814.x

Zapf, D. (1999). Organisational, work group related and personal causes of mobbing/ bullying at work. International Journal of Manpower, 20(1/2), 70-85. https://dx.doi. org/10.1108/01437729910268669

Zapf, D., \& Einarsen, S. (2011). Individual antecedents of bullying: Victims and perpetrators. In S. Einarsen, H. Hoel, D. Zapf \& C. L. Cooper (Eds.), Bullying and harassment in the workplace: Developments in theory, research and practice (2nd ed., pp. 177-200). London, UK: Taylor \& Francis.

Zapf, D., Escartin, J., Einarsen, S., Hoel, H., \& Vartia, M. (2011). Empirical findings on prevalence and risk groups of bullying in the workplace. In S. Einarsen, H. Hoel, D. Zapf, \& C. L. Cooper (Eds.), Bullying and harassment in the workplace: Developments in theory, research and practice (2nd ed., pp. 47-71). London, UK: Taylor \& Francis.

Zapf, D., Knorz, C., \& Kulla, M. (1996). On the relationship between mobbing factors, and job content, social work environment, and health outcomes. European Journal of Work and Organizational Psychology, 5(2), 215-237. http://dx.doi.org/10.1080/13594329608414856 